\title{
Community structure, succession and development of coral reefs in Hawaii*
}

\author{
Richard W. Grigg \\ Hawaii Institute of Marine Biology, P.O. Box 1346, Kaneohe, Hawaii 96744, USA
}

\begin{abstract}
Reef building corals in the Hawaiian Archipelago consist of only 42 species belonging to 16 genera. The Hawaiian coral fauna is highly depauperate relative to the Indo-West Pacific Ocean, a result most likely due to geographic isolation. Although impoverished, the species composition of reef building corals is remarkably uniform throughout the archipelago. Differences in species composition which do exist appear to be caused by varying patterns of disturbance and recruitment. Although patchy distributional patterns exist within islands, the differences in species composition between islands are small. Where adequate substrata prevail within the euphotic zone most species are present. Hence species composition tends to be an all or none phenomenon. Contrary to most terrestrial ecosystems, a positive correlation does not exist between species richness and habitat area $(0$ to $20 \mathrm{~m})$. This may be due to low habitat complexity within the zone for reef building corals and high rates of recruitment between islands. It also suggests that most reef building corals in Hawaii are generalized species. The fact that most do not drop out moving northwestward in the chain is evidence of their generalized life history (eurytopy). The most significant differences between coral reefs found on different islands, are differences in community structure. On seaward reefs differences in community structure appear to be primarily caused by differences in physical disturbance from long period swell; they can be interpreted as differences in successional age. Moving northwestward within the chain, coral growth rates steadily decline. This has the effect of lengthening the successional process and increasing the likelihood of intervening disturbance. A hypothetical model operational over generations is presented demonstrating the effect of disturbance on the successional process for coral reefs in general. The development of large-scale morphological features such as spurs and grooves, fringing and barrier reefs and atolls involve processes operational over geological periods of time. The chronology of the Hawaiian Archipelago is now sufficiently well known to serve as a time scale against which the development of these structures can be measured.
\end{abstract}

\section{INTRODUCTION}

In 1969 Thomas Goreau suggested that modern reefs are youthful assemblages, less than 5,000 yr old, still undergoing post-Pleistocene successional changes (Goreau, 1969). More recent work displaced the date when Holocene reef growth began to between 6,000 and 9,000 yr B. P. (Macintyre and Glynn, 1976; Adey, 1978) and distinguished between reef morphogenesis (development) which occurs over geological periods of time $(1,000$ 's of years) from successional events that occur over generations (Grigg and Maragos, 1974; Connell, 1978; Pearson, 1981).

In 1974, Grigg and Maragos first proposed a model for coral community succession based on patterns of

\footnotetext{
- Contribution No. 640 of the Hawaii Institute of Marine Biology, Kaneohe, Hawaii 96744, USA
}

recolonization on submerged historic lava flows in Hawaii. By piecing together data sets from progressively older flows they found that diversity first increased but then gradually decreased as more and more species became established. They hypothesized that the decline in diversity on older flows was due to space limitation and competitive exclusion by dominant species, a process which took over $50 \mathrm{yr}$. Grigg and Maragos also found that many reefs were constantly disturbed and never reached a climax stage.

In 1978, Connell described a similar pattern for Great Barrier Reef coral communities and Australian tropical rain forests and erected the intermediate disturbance hypothesis' (Connell, 1978). In Connell's classic paper, this and several other hypotheses based on ecological theory were considered as possible mechanisms responsible for maintaining the diversity of these kinds of ecosystems. Intermediate disturbance 
was defined in terms of time (frequency), space (area affected) and intensity (magnitude). Connell concluded that under most conditions, the high diversity normally found on coral reefs is maintained by disturbance operating at intermediate levels, although he emphasized that in certain cases, other mechanisms (e.g. chance recruitment, climatic change, niche diversification, competitive hierarchies and compensatory mortality) could be of equal or greater importance in maintaining diversity.

Tests of ecological theory are strengthened when observations or measurements are conducted in replicate under differing ecological conditions. In the Hawaiian Archipelago a large number $(>100)$ of islands, atolls, banks or shoals provide shallow foundations for the development of coral reefs. These extend from $19^{\circ} \mathrm{N}$ to $29^{\circ} \mathrm{N}$ latitude which is the northern limit of atolls in the Pacific Ocean (Dana, 1971). Across these latitudes, gradients or differences in temperature, light, nutrient concentration, primary productivity, thermal stratification, larval colonization (currents), island age, size and morphology exist (Sechel, 1962; Grigg and Dollar, 1980; Hirota, 1980). Differences in island size and morphology also produce differences in shelter to open sea and swell. Hence the Hawaiian Archipelago represents a unique natural laboratory where the effects of a variety of physical and biological factors can be determined.

In this paper patterns of coral community structure and calcification throughout the archipelago are described and analyzed with respect to the geographic distribution of relevant environmental variables. The data are also used as a test of the intermediate disturb- ance hypothesis regarding the maintenance of diversity of coral communities throughout the Hawaiian Archipelago,

\section{METHODS}

The community structure of coral communities was determined by measures of species presence, species diversity (Shannon Weaver Index for cover $\mathrm{H}_{\mathrm{c}}^{\prime}$ ), equitability $\left(J_{c}\right)$, dominance and rank order of species dominance. These data were collected at stations selected off 14 major islands, atolls and reefs in the Archipelago, including Hawaii, Maui, Oahu, Kauai, Nihoa, Necker, French Frigate Shoals, Gardner Pinnacles, Maro Reef, Laysan, Lisianski, Pearl and Hermes, Midway and Kure (Fig. 1). At each island, most stations were located off southwestern exposures at depths close to $10 \mathrm{~m}( \pm 3 \mathrm{~m})$. Emphasis was placed on the southwestern sector because in the belt of northeast trades in the tropical Pacific Ocean, the best developed seaward reefs occur off southwestern coasts (Maragos, 1977; Dana, 1979). This design also served to standardize interisland comparisons of species composition, community structure, diversity and rates of calcification. Other habitats, particularly lagoons, were also surveyed to the extent practical given constraints in weather and time.

At each station, either a $50 \mathrm{~m}$ or two $25 \mathrm{~m}$ long transect lines were placed on the bottom along approximately $10 \mathrm{~m}$ isobaths. A rectangular quadrat $\left(0.67 \mathrm{~m}^{2}\right)$ with a camera mounted on a tripod was then placed over 10 random points marked on the transect line(s). Data were recorded on film as well as in situ where

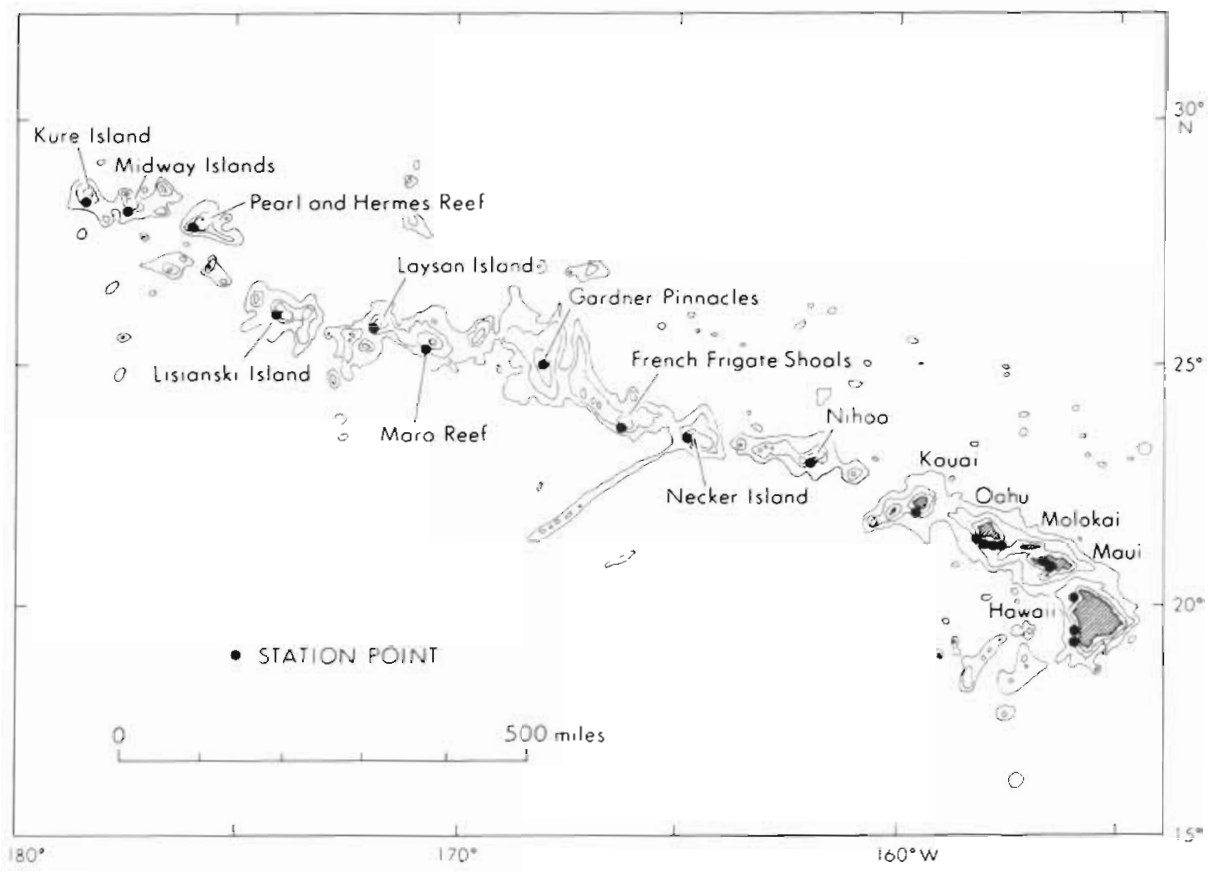

Fig. 1 Hawaiian Archipelago with location of all stations 
visual estimates of the percent cover occupied by all macroscopic $(>2 \mathrm{~cm})$ species were tabulated. Emphasis was placed on species occupying the majority of space since they appear to dominate community structure. All photographic slides for each transect were later projected in the laboratory against a standard grid (screen) with 100 divisions. The cover occupied by each species was integrated by summing all the squares occupied by each species. Field observations were made to aid in species recognition and to determine the condition of the substratum and living cover. Virtually all abundant corals at each station were represented on the transects. In addition to transects, an area about $5000 \mathrm{~m}^{2}$ at each station was surveyed qualitatively in order to compile a more complete species list and more representative estimates of abundance for rare species and species with aggregated distributions. Over this area, species represented by individuals or colonies numbering more than 50 were considered abundant, 10 to 50 as common, 3 to 10 as uncommon and 1 to 3 as rare

Physical variables important in characterizing the habitat were also recorded at each station. These included: depth, area of habitat, bottom relief, substratum type, sediment cover, proximity to sediment, bottom slope, distance to emerged land, relative degree of exposure to open sea and swell, temperature, bottom current and surge, wave climate, wind, and a general description of the area. Data for variables for which instantaneous measurements are of limited application but are important over the long term such as solar radiation, temperature, long period swell, and wind were obtained from various sources including atlases, the National Weather Service and records of the US Navy Oceanographic Office.

Off every island selected for study the growth rate of Porites lobata was measured at the $10 \mathrm{~m}$ southwest sector stations and applied to a ll coral species present to produce estimates of gross carbonate production by corals (see Grigg and Dollar, 1980, for a complete description of the method). These values were used as estimates of the maximum potential of coral accretion. In the main, the results of this work have been described elsewhere (Grigg, 1981a, 1982). They are considered here in terms of their effects on community structure and succession.

\section{ENVIRONMENTAL SETTING}

The Hawaiian Islands and the Emperor Seamounts comprise the longest contiguous chain of islands, guyots and seamounts in the world. The archipelago is 1,450 miles long; although it is not continuous, the chain covers a distance greater than the Great Barrier Reef in Australia. Most geologists now agree that the

Table 1. Island area, reef area (habitat), rank shelter, coral species number, coral cover, temperature and solar radiation for the Hawaiian Islands

\begin{tabular}{|c|c|c|c|c|c|c|c|}
\hline Island & $\begin{array}{c}\text { Island } \\
\text { area } \\
\left(\mathrm{km}^{2}\right)\end{array}$ & $\begin{array}{l}\text { Rank }{ }^{(b)} \\
\text { shelter }\end{array}$ & $\begin{array}{c}\text { Reef area } \\
\left(\mathrm{km}^{3}\right) \\
0-20 \mathrm{~m}^{(\mathrm{c})}\end{array}$ & $\begin{array}{l}\text { Species } \\
\text { coral }^{(e)}\end{array}$ & $\begin{array}{l}\text { Mean } \\
\text { coral } \\
\text { cover }^{(t)}\end{array}$ & $\begin{array}{l}\text { Mean annual } \\
\text { surface } \\
\text { temperature }\end{array}$ & $\begin{array}{l}\text { Mean } \\
\text { solar }^{(h)} \\
\text { radiation }^{(h)}\end{array}$ \\
\hline Hawaii & 10450.0 & 1 & 224.0 & 15 & 67 & 25.15 & 388 \\
\hline Maui & 1886.0 & 2 & 206.4 & 12 & 49 & 24.92 & 381 \\
\hline Oahu & 1573.0 & 3 & 287.8 & 16 & 54 & 25.04 & 386 \\
\hline Kauai & 1431.0 & 9 & 218.0 & 12 & 51 & 25.11 & 383 \\
\hline Nihoa & 0.771 & 12 & 0.6 & 12 & 25 & 25.01 & 381 \\
\hline Necker & 0.235 & 13 & 2.1 & 13 & 16 & 25.08 & 378 \\
\hline FFS $^{d}$ & 343.0 & 4 & 494.0 & 22 & 69 & 25.15 & 361 \\
\hline Gardner & 0.01 & 14 & 3.0 & 14 & 8 & 24.77 & 369 \\
\hline Maro $^{d}$ & 192.0 & 5 & 390.0 & 21 & 54 & 24.72 & 365 \\
\hline Laysan & 3.95 & 11 & 45.4 & 18 & 40 & 24.69 & 367 \\
\hline Lisianski & 1.75 & 10 & 325.3 & 17 & 24 & 24.72 & 359 \\
\hline Pearl \& Hermes ${ }^{d}$ & 382.0 & 6 & 447.0 & 12 & 19 & 24.00 & 347 \\
\hline Midway & 92.3 & 7 & 92.2 & 14 & 11 & 23.71 & 341 \\
\hline Kure & 66.0 & 8 & 78.1 & 13 & 9 & 23.71 & 343 \\
\hline $\begin{array}{l}\text { a Atlas of Hawaii, } \\
\text { b Based on shelter } t \\
\text { " Measured by inte } \\
\text { d Area enclosed by } \\
{ }^{\text {e }} \text { Species count for } \\
{ }^{2} \text { Mean of seaward } \\
{ }^{g} \text { Atlas of N. Pacific } \\
{ }^{b} \text { Mean daily solar }\end{array}$ & $\begin{array}{l}\text { niversity of } \\
\text { tradewind } \\
\text { ration of are } \\
\text { parrier reef } \\
11 \text { habitats } \\
\text { ransects on } \\
\text { monthly me } \\
\text { adiation for }\end{array}$ & $\begin{array}{l}\text { aii Press } \\
\text { rated sea } \\
\text { tween } 0\end{array}$ & $\begin{array}{l}\text { long period } \\
\mathrm{m} \text { isobath }\end{array}$ & $\begin{array}{l}\text { s of the sur } \\
\text { er et al., } 15\end{array}$ & ayer (Rob & Son, 1976). Units & $=\mathrm{C}^{\circ}$ \\
\hline
\end{tabular}


Hawaiian Archipelago formed from massive eruptions through a relatively stationary 'hot spot' in the Pacific lithospheric plate as it gradually drifted to the north and northwest (Wilson, 1963; Morgan, 1972; Jackson et al., 1980). The island of Hawaii, which contains the only active volcanoes in the chain, is believed to be situated over the hotspot. It is less than 1 million yr in age. To the northwest, the islands are progressively older and gradually decrease in size due to subsidence and erosion. The last remnant of basalt present above sea level in the chain is Gardner Pinnacles $\left(25^{\circ} \mathrm{N}\right)$ (Fig. 1). All islands further to the northwest are either atolls or coral islands or reefs and shoals of limestone construction. Midway atoll, next to the last island in the chain, is about $27.7 \pm 0.6 \mathrm{~m}$.yr in age (Dalrymple et al., 1977). Beyond Kure, the chain continues as a series of drowned atolls (guyots) and seamounts which extend all the way to Kamchatka (Jackson et al., 1980).

Physical, chemical and biological conditions of waters surrounding the Hawaiian Archipelago have

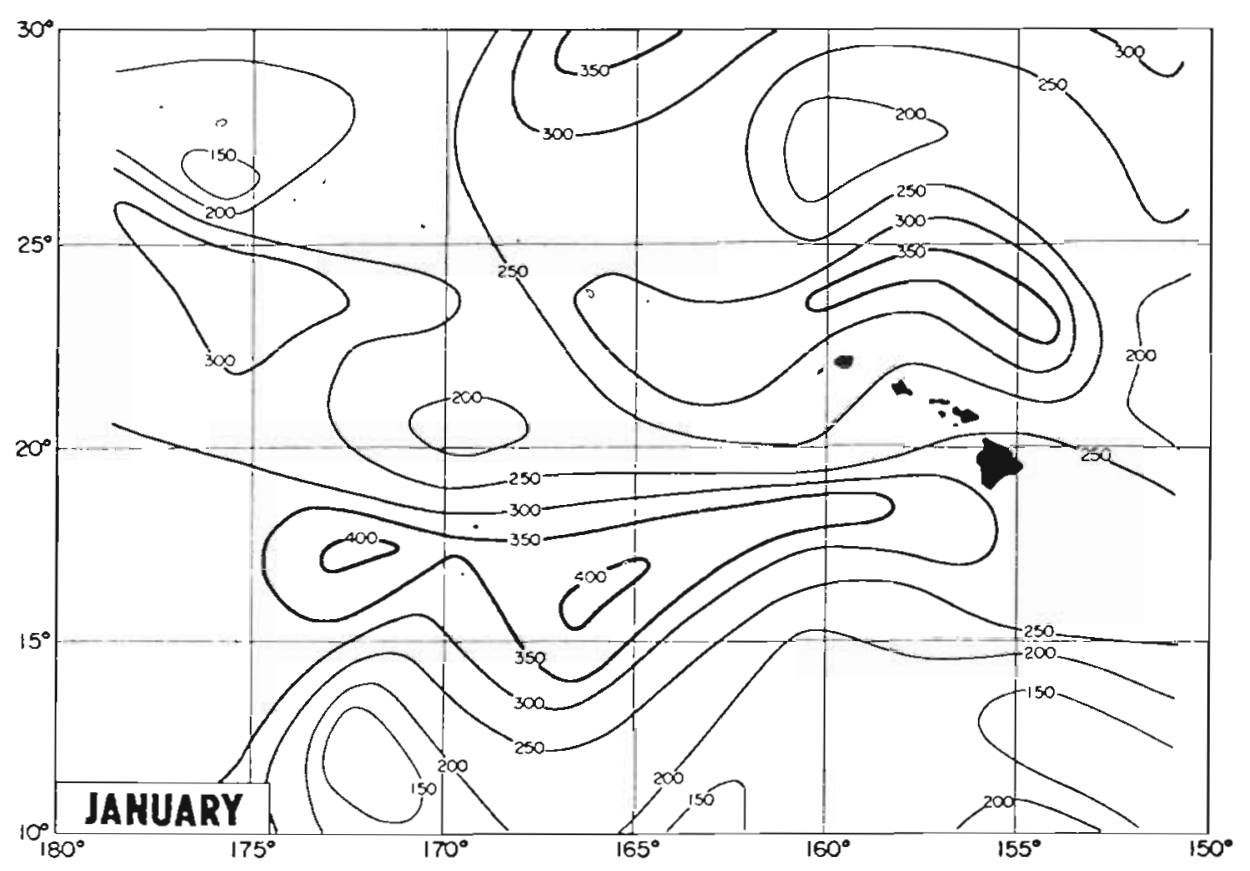

Fig. 2. Distribution of depth of mixed layer (depth in $\mathrm{ft}$ ) in January (top) and July (bottom). (After Sechel, 1962)

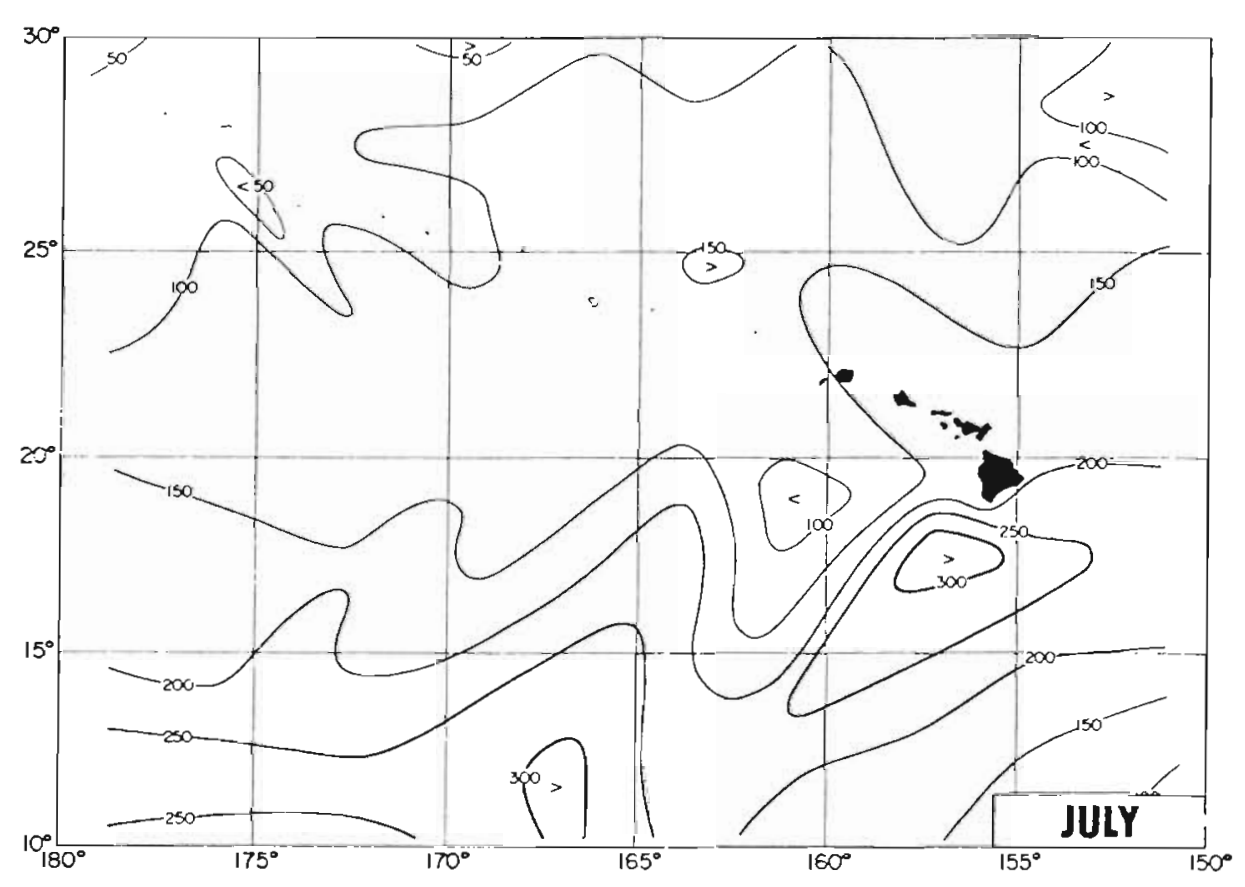


been summarized or reviewed best by Sechel (1962), Robinson (1969), Wyrtki et al. (1969), Patzert et al. (1970), and Hirota et al. (1980). Although oceanic conditions are relatively uniform along the archipelago in terms of salinity, $\mathrm{O}_{2}$, nitrate, particulate carbon, chlorophyll a, phaeopigments, and zooplankton, waters around the Northwestern Islands are slightly more productive $(40 \%)$ than off the major high islands (Hirota et al., 1980). Also moving to the northwest, several physical gradients exist across the archipelago. The most obvious is solar radiation (Table 1) which steadily declines with increasing latitude. Average daily solar radiation corrected for cloud cover (Sadler et al., 1976) was integrated over the year for all islands (Table 1). Average annual values ranged between 388 Langleys $\mathrm{d}^{-1}$ off leeward Hawaii to 341 Langleys $\mathrm{d}^{-1}$ at Midway Island, a difference of $14 \%$. Another important physical gradient across the archipelago is depth to the thermocline which steadily decreases to the northwest (Fig. 2). The decrease is particularly pronounced during summer months (compare 250 feet off Hawaii in July to 50 feet off Kure in July, Fig. 2).

Sea surface temperature differences are strongly seasonal (Fig. 3); during summer there are almost no differences across the chain, whereas in winter, differences average about $3 \mathrm{C}^{\circ}$ but may be as large as $6 \mathrm{C}^{\circ}$ (Fig. 3, Table 1). At both ends of the archipelago seasonal differences are more pronounced nearshore than in oceanic environments (Fig. 3)

Another obvious difference between the major high islands and the northwestern Hawaiian Islands are ecological impacts associated with urbanization. By and large such effects are limited to the major high islands where urban centers exist. The most damaging

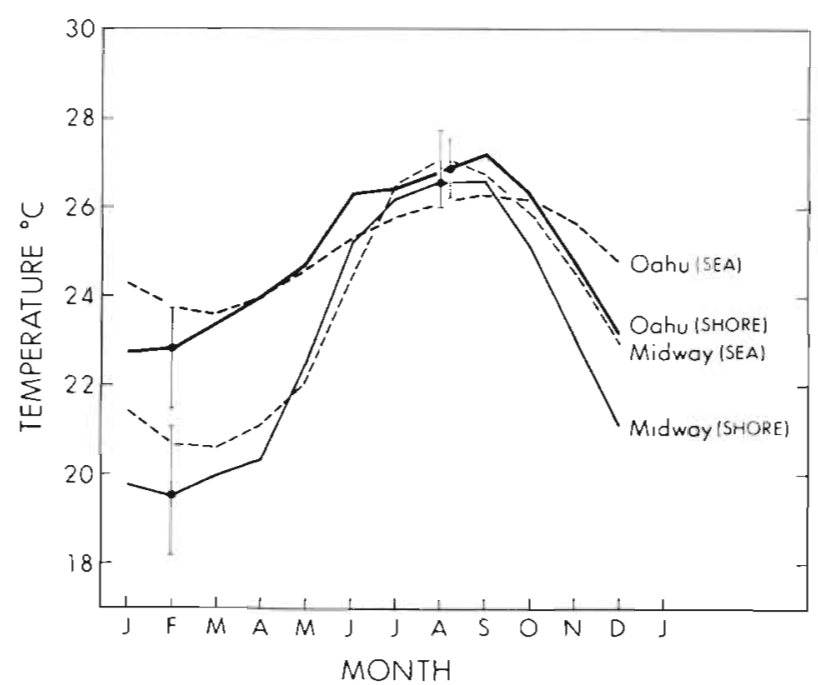

Fig. 3. Mean monthly temperature off Oahu and Midway Island. Nearshore and offshore stations shown; vertical bars: range for shore stations. (Shore data from Jokiel and Coles, 1977; sea data from Table 1, this paper) sources of pollution include sedimentation caused by run-off, sugar-mill discharges and sewer outfalls (Grigg, 1972; Maragos, 1972; Johannes and Wood, 1975) and eutrophication in confined bays due to sewage disposal (Smith et al., 1973). While anthropogenic impacts are occasionally severe, effects are localized and there is no evidence of disturbance from these sources on the scale of islands. The same conclusion can be applied to the effects of natural stresses associated with high islands (fresh water run-off from rivers, high rates of sedimentation and turbidity).

Differences in geographic position within the chain are not of great significance with respect to exposure to long period swell. Although the northwestern end of the chain is closer to winter storm tracks in the north Pacific Ocean, some storms moving east do not become fully developed until they are north of the major high islands which receive the brunt of storm waves from these systems. Of greater importance than geographic position, is the degree of shelter afforded by island size and bathymetry. The relationship between island size (flat surface area) and shelter for stations off southwest sectors is given in Table 1. Wave shelter was assessed by assigning ranks to island stations based on their exposure to seas generated by local winds and long period swell for each month integrated over a year. The correlation between island area and shelter for southwest sector stations is significant ( $\mathrm{r}=-0.54$, $\mathrm{p}=.05$ ) suggesting that island area can be used as a measure of shelter to waves for these stations.

Differences in large-scale current systems within the archipelago are important to species composition and community structure because they affect larval colonization. For the marine biota of the Hawaiian Archipelago there appears to be at least 3 present-day routes of colonization by way of currents all with roots in the Indo-West-Pacific. Strong faunal ties between Hawaiian and Japanese faunal elements suggest that the 2 sources of larval colonization are the North Pacific drift (Hobson, 1980) and the southern extension of the Kuroshio (Zinmeister and Emerson, 1979). A third route from the southwest appears to be by way of the Subtropical Counter-current possibly via Johnston Atoll (Grigg, 1981b) or the Line Islands (Kay, 1980). Northwestward drift of islands on the Pacific lithospheric plate (island integration) may have been a fourth 'route' of colonization during the Miocene (Rotondo et al., 1981). Also some now submerged MidPacific Mountains were at sea level during the early Tertiary and may have then served as stepping stones for larval colonization during the earliest period of Hawaiian volcanism when the Emperor Seamounts were above sea level at latitudes much further south of their present location (Jackson et al., 1980). Such species, however, may not have survived widespread 
extinctions during the Eocene (Kay, 1980). In any case the Hawaiian Archipelago is probably the most isolated chain of islands in the world and at best the biota must be considered impoverished (Maragos, 1977).

\section{RESULTS}

\section{Species composition}

Of the 42 species of hermatypic corals documented from the Hawaiian Archipelago (Maragos, 1977; Grigg et al., 1981), 24 or $57 \%$ were recorded from stations surveyed during this study (Table 2). All large and abundant species which significantly affect community structure, succession and reef development of coral reefs in Hawaii are well represented in the data sets. Most of the species not recorded are small and rare or restricted to deeper water. Several species of Porites not recorded (evermanni, pukoensis, duerdeni) are difficult to distinguish in the field from $P$. lobata (the first two) and $P$. compressa (the third) and therefore the list may actually represent 27 species. Included in the list are 3 species of Acropora not previously known from Hawaii (Grigg et al., 1981).

Differences in species composition between the islands are in general relatively small (Fig. 4, Table 2). A priori, it was expected that species would gradually 'drop out' to the northwest because of less optimal conditions of temperature and light. Also, it is well known that the diversity of most taxonomic groups in the sea and on land declines with increasing latitude. However, instead of declining, a peak in species diversity was found in the middle of the chain at French Frigate Shoals and Maro Reef. In part, this peak is due to increased collecting effort at these islands (Fig. 5), however, when corrected for this effect the islands in the middle of the chain are still the most diverse. Some of the difference at French Frigate Shoals and Maro

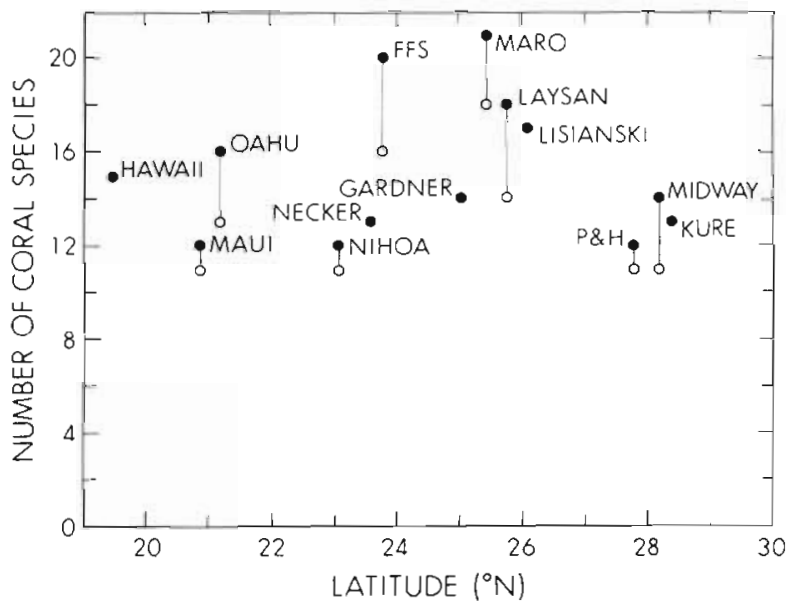

Fig. 4. Number of hermatypic coral species recorded at each island. Open circle: after 3 transects; solid circle: total transects (southwest sector)

Table 2. Presence of hermatypic corals on all transects in the Hawaiian Archipelago

\begin{tabular}{|c|c|c|c|c|c|c|c|c|c|c|c|c|c|c|}
\hline & Hawaii & Maui & Oahu & Kauai & Nihoa & Necker & FFS & Gardner & Maro & Laysan & Lis & P.H. & Mid & Kure \\
\hline P. lobata & $x$ & $x$ & $x$ & $x$ & $x$ & $x$ & $\times$ & $\times$ & $x$ & $\times$ & $x$ & $x$ & $x$ & $x$ \\
\hline$P$. compressa & $x$ & $x$ & $x$ & $\times$ & & $\times$ & $\times$ & $x$ & $x$ & $x$ & $x$ & $x$ & $x$ & $x$ \\
\hline P. meandrina & $x$ & $x$ & $x$ & $x$ & $x$ & $x$ & $x$ & $x$ & $\times$ & $x$ & $x$ & $x$ & $x$ & $\times$ \\
\hline M. verrucosa & $x$ & $x$ & $x$ & $x$ & $x$ & $x$ & $\times$ & $\times$ & $x$ & $x$ & $x$ & $x$ & $\times$ & $x$ \\
\hline M. patula & $x$ & $x$ & $x$ & $x$ & $x$ & $x$ & $x$ & $x$ & $x$ & $x$ & $x$ & $x$ & & \\
\hline M. flabellata & $x$ & $x$ & $x$ & & $x$ & & $x$ & & $x$ & $x$ & $x$ & $x$ & $\times$ & $x$ \\
\hline M. dilitata & & & $x$ & & & & $\times$ & & $x$ & $x$ & $\times$ & $x$ & & \\
\hline P. eydouxi & $x$ & $x$ & $x$ & $x$ & $x$ & $x$ & $x$ & & $x$ & $x$ & & $x$ & & $x$ \\
\hline P. ligulata & & & & & & & $\times(\mathrm{L})$ & & $x$ & & $x$ & & & \\
\hline P. damicornis & $x$ & & & & & & $\times(\mathrm{L})$ & & $\times$ & & $x$ & $\times(\mathrm{L})$ & & \\
\hline P. varians & $x$ & $x$ & $x$ & $x$ & & $x$ & $x$ & $x$ & $\times$ & $x$ & & $\times$ & $x$ & $x$ \\
\hline$P$. duerdeni & $x$ & & $x$ & $x$ & $x$ & $x$ & $\times$ & $\times$ & $x$ & $x$ & $x$ & $x$ & $x$ & $x$ \\
\hline P. pollicata & & $x$ & & & & & & & $x$ & $x$ & $\times$ & $\times(L)$ & $x$ & $x$ \\
\hline P. brigami & & $x$ & $x$ & $x$ & $x$ & $x$ & $x$ & $x$ & $\times$ & $x$ & $x$ & & $x$ & \\
\hline P. (s) convexa & $x$ & & $x$ & & $x$ & $x$ & $x$ & & & $x$ & $x$ & & $x$ & $x$ \\
\hline$L$ purpurea & $\times$ & $x$ & $x$ & $x$ & $x$ & $\times$ & $\times$ & $\times$ & $\times$ & $x$ & $\times$ & $x$ & $x$ & $x$ \\
\hline L. bottae & & & & $\times$ & & $x$ & $x$ & $\times$ & $x$ & & & & & \\
\hline Cocellina & $x$ & & $x$ & $x$ & $x$ & $x$ & $\times$ & $x$ & $x$ & $x$ & $x$ & $\times$ & $x$ & $\times$ \\
\hline$P$. stellata & & $x$ & $x$ & & & & $x$ & $\times$ & & & $\times$ & $\times(\mathrm{L})$ & $x$ & $x$ \\
\hline F. scutaria & $x$ & & $x$ & & & & $\times$ & $x$ & $x$ & $x$ & $x$ & $\times(\mathrm{L})$ & $\times$ & \\
\hline A. cytherea & & & & & $x$ & & $x$ & $x$ & $x$ & $x$ & & & & \\
\hline A. valida & & & & & & & $x$ & & $x$ & & & & & \\
\hline A. humilis & & & & & & & $x$ & & $x$ & & & & & \\
\hline $\mathrm{L}=$ Lagoon & & & & & & & & & & & & & & \\
\hline
\end{tabular}




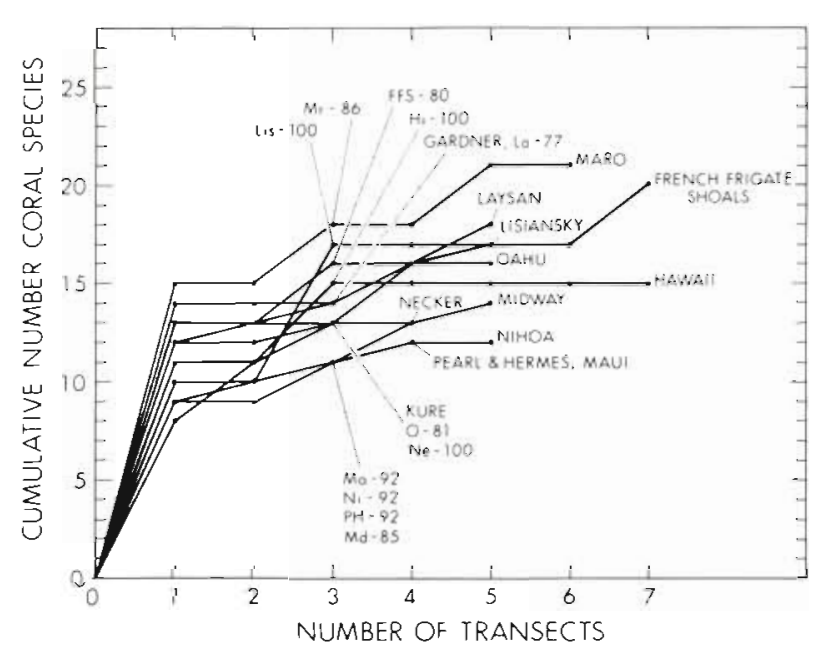

Fig. 5. Cumulative species per transect in southwest sectors for all islands. After 3 transects, from 77 to $100 \%$ of species had been recorded on every island

Reef is due to the presence of 3 species of Acropora: $A$. cytherea, $A$. valida and $A$. humilis. Also the genus Montipora seems to predominate in the central and north central islands where 4 species are exceedingly abundant (Table 2). When the abundance patterns of all species are taken into account, a small diversity peak $\left(\mathrm{H}^{\prime} \mathrm{c}\right)$ is evident in the middle of the chain (Fig, 6), however, the overall pattern is relatively uniform.

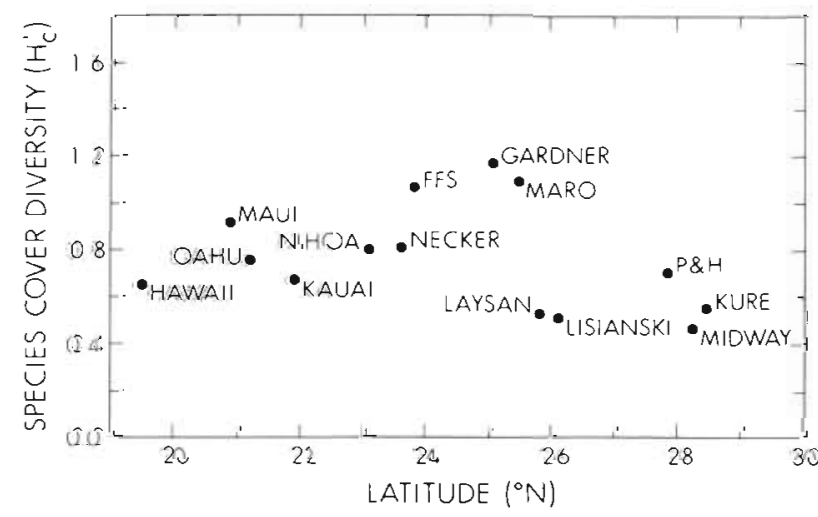

Fig. 6. Species diversity $\left(\mathrm{H}_{c}^{\prime}\right)$ for hermatypic corals recorded at each island (southwest sector)

\section{Community structure}

The most significant difference in community structure between islands in the archipelago as represented by stations off southwest exposures is the degree of dominance by individual species (Fig. 7). At stations off large islands such as Hawaii, Maui and Oahu, either Porites lobata or $P$. compressa is generally dominant. The diversity at these stations is relatively low because equitability is low, i. e. community structure is dominated by a few species. In contrast, at stations off small islands or atolls, no species dominates and equitability is relatively high. Islands of intermediate size exhibit an intermediate pattern.

Another striking difference in community organization of corals between islands is the inconsistency in their rank order abundance (Fig. 7). Although Porites lobata is generally the most abundant species at all southwest sector stations surveyed in the archipelago, the position of the second most abundant species varies considerably between $P$. compressa, A. cytherea $M$. verrucosa, $P$. meandrina and $P$. duerdeni.

Other marked discontinuities include some soft corals and many invertebrates. For example, the soft corals Palythoa tuberculosa and Sinularia abrupta are both very abundant at Nihoa Island but are much rarer or absent on the other islands. Similar patchiness was noted for several invertebrate groups, including Acanthaster planci which was very abundant at Necker Island in 1978 but rare everywhere else surveyed. Approximately 200 individuals were counted in a $5000 \mathrm{~m}^{2}$ area at Necker in 1978. A survey in the same area in 1980 failed to produce a single starfish, demonstrating the temporal as well as spatial variability of this species. Other species with striking patterns of spatial heterogeneity include the starfish Mithrodia fisheri and the sponge Spongia oceania which were common at Nihoa in 1978 and 1980 but rare everywhere else in the archipelago. Patchiness may also be characteristic for entire groups of species. For example, the number of species of molluscs (14) found at French Frigate Shoals was much greater than on any other island. The most extreme example of patchiness found in the archipelago was a distinctive ascidian (Archidistoma [Eudistoma] angolanum [Michaelsen, 1914]) found only at Gardner Pinnacles where it was very abundant in 1980 .

\section{Reef development}

It has been shown elsewhere (Grigg, 1981a, 1982) that rates of calcification and reef accretion due to corals steadily decline to the northwest in the archipelago. Approximately two-thirds of the variability in growth across the archipelago is accounted for by changes in temperature and light (Grigg, 1982). At the northwestern end of the chain a threshold for atoll formation exists which has been called the Darwin Point (Grigg. 1982). Measurements of the growth rates of living coral at the Darwin Point suggests that corals only provide about $20 \%$ of the calcium carbonate necessary to keep pace with changes in sea level at this latitude. Since all the islands in the chain are 

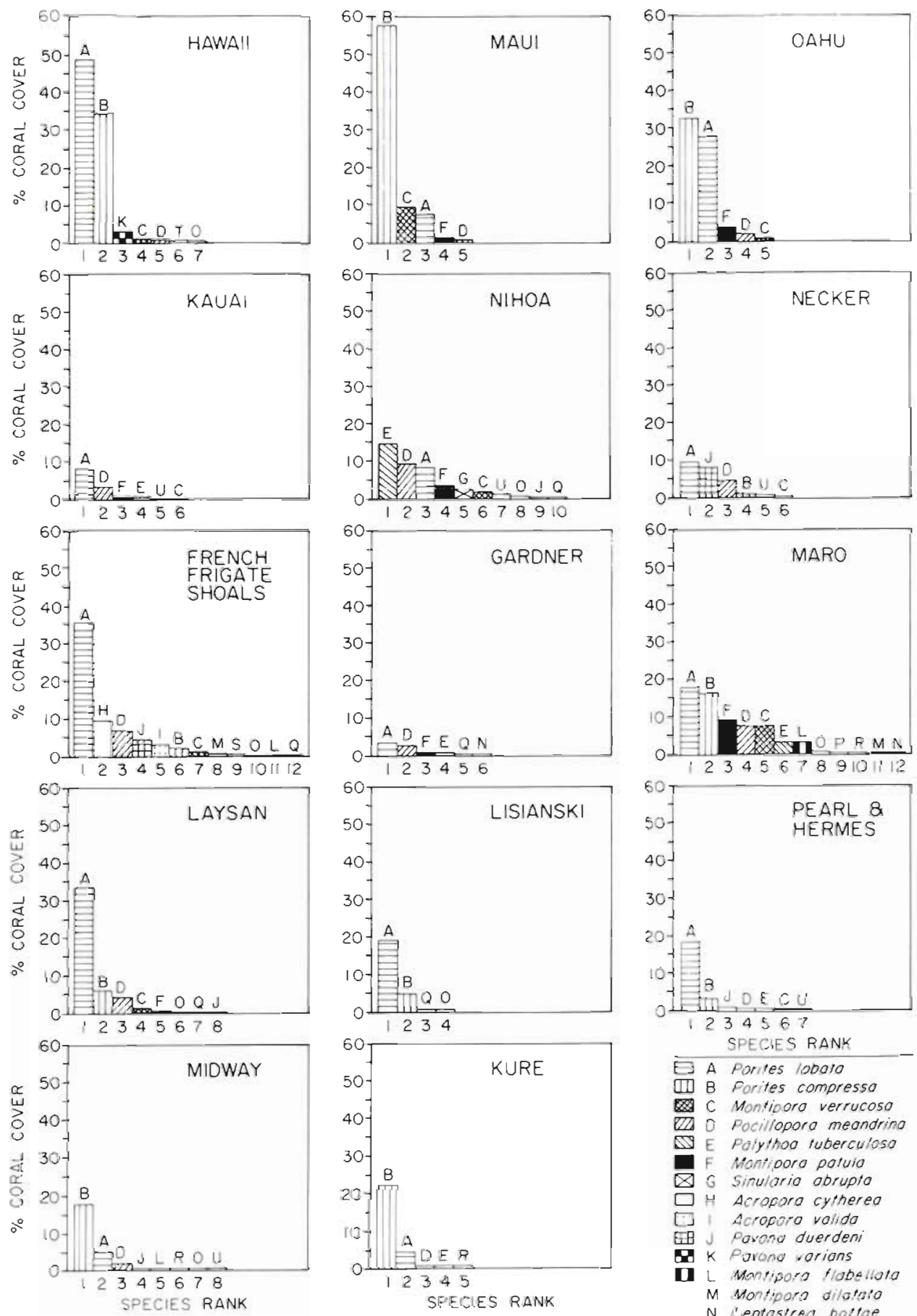

PERCENT CORAL COVER VS SPECIES RANK OF ABUNDANCE

MEAN CORAL COVER FOR ALL SPECIES ON ALL TRANSECTS COMBINED FOR EACH ISLAND

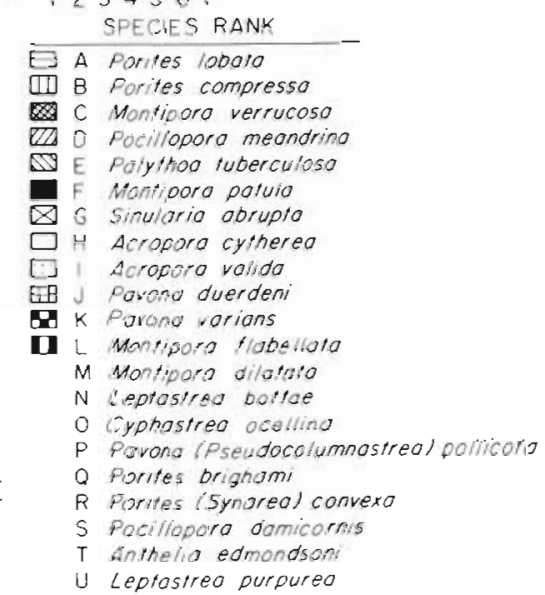

Fig. 7. Community structure of coral communities as measured by percent coral cover plotted against species rank order of abundance for all offshore southwest sector stations for all islands 
gradually eroding and subsiding as they slowly drift to the northwest due to seafloor spreading (Jackson et al., 1980) many have reached the Darwin Point, drowned, and are now guyots northwest of Kure Atoll.

Recent geophysical studies have produced estimates of the dates when all of the major islands ceased major volcanic activity. In cases where coral deposits overlie dated basalts it is possible to calculate the time required for the development of various reef morphologies. The youngest island is Hawaii at the southeastern end of the chain. Hawaii is less than 1 million yr old and is still volcanically active. Moving to the northwest all the islands progressively increase in age. French Frigate Shoals is about 12 million yr. Midway near the northwestern end is almost 28 million yr (Dalrymple et al., 1977). The oldest coral growth at Midway is estimated at $15.7 \pm 0.9$ million yr based on a $\mathrm{K} / \mathrm{Ar}$ date of volcanic rock from the base of a reef core taken from a depth of $384 \mathrm{~m}$ below sea level (Ladd et al., 1967).

On the big island of Hawaii, most shorelines have been extended by volcanic activity during recent time, therefore extant reefs including their carbonate foundations are probably all Holocene in age having formed in the last 6,000 to 9,000 yr. Since a spur and groove morphology is well developed on some reefs on Hawaii, 6,000 to 9,000 yr is apparently sufficient time for their development. The formation of larger scale features such as fringing and barrier reefs probably depends on many other factors in addition to time, such as island size, subsidence rate, coral growth rates, exposure to waves, firmness of the substrate and so on. Nevertheless, it is instructive to use the time frame provided by knowledge of the evolution of the Hawaiian chain to serve as an estimate of the time required for their formation. The youngest fringing reef found in the Hawaiian chain is outside Kaneohe Bay on Oahu dated at about 2.5 million yr (Schlanger and Gillett, 1976). The first atoll or nearly so (a small remnant of basalt 41 meters in elevation remains above sea level) is found at French Frigate Shoals which is estimated to be $11.7 \pm 0.4$ million yr in age. This is the youngest true barrier reef in the archipelago.

\section{DISCUSSION}

It is important to distinguish between 2 major time scales regarding the development of coral reefs in the Hawaiian Archipelago. The first is on the order of thousands or millions of years and applies to the development of large-scale morphological features such as spur and grooves, fringing reefs, barrier reefs and atolls. In the case of the Hawaiian Archipelago which is the most isolated set of islands in the world, this time scale might also apply to initial rates of colonization. The second time scale is much shorter, on the order of generations of dominant species, and appears to apply to processes which determine species composition and community structure; that is, rates of intra and inter-island recruitment, recruitment from fragmentation (Highsmith, 1982), rates of growth and rates of mortality. A more explicit definition of this time scale might be the time required for the completion of the successional process.

Before looking at species composition of individual islands, mention should be made of the impoverished character of the coral fauna in Hawaii (Edmondson, 1946; Stehli and Wells, 1971; Maragos, 1977). Only 42 species of reef building corals belonging to 16 genera are found in Hawaii. This compares to about 65 genera in the Indo-West-Pacific region (Pichon, 1977). Dana (1971) has argued that much of this difference is due to isolation and pointed out that more than 200 species of reef building corals are found in Japan which is exposed to much harsher environmental conditions but is not as isolated from the Indo-West-Pacific region. In terms of ecological theory, the isolated geography of the Hawaiian Islands and their small size would be expected to produce low rates of recruitment and high rates of mortality (Macarthur and Wilson, 1967).

Returning to the results of this study, differences in species composition between the islands were found to be generally small. Also there does not appear to be a consistent latitudinal trend. For example, the number of coral species recorded from the islands of Hawaii and Kure, at opposite ends of the chain, are 15 and 13, respectively. Dana (1971) reported 18 species from Kure Atoll but this count was based on considerably more collecting effort than our surveys. The only significant departure from uniformity evident in the data reported here is a peak in species number and diversity in the middle of the chain. This peak is associated with the presence of 3 species of Acropora. The distributional pattern of these 3 species and the lack of evidence of their sexual reproduction in Hawaii suggests that at least in part the diversity peak in the center of the chain is due to active colonization from outside the archipelago. An analysis of currents in the region suggests the source is Johnston or Wake Island by way of the Subtropical Countercurrent (Grigg, 1981a). At least 1 species of fish (Chaetodon trifascialis) and several invertebrates (the ascidian at Gardner Pinnacles, the opistobranch Cassella and the nudibranch Pleurobranchia) which are also restricted to the center of the chain may also owe their existence in Hawaii to this route of colonization.

The fact that species do not drop out as the latitudinal extreme (the Darwin Point) is approached suggests 
that in terms of species composition, the formation of coral communities in Hawaii is an all or none phenomenon. Disregarding species of Acropora which appear to be expatriots, approximately the same number of species of hermatypic coral appears to be present on every island regardless of size or age. Even if Acropora spp. are included, the correlation between habitat area $(0$ to $20 \mathrm{~m})$ and number of species of coral for all islands is positive but not significant $(r=0.44$, $\mathrm{p}>.05$; see Columns 4 and 5 in Table 1 ). This finding is surprising, since in terrestrial ecosystems the relationship between number of species and island area is well established (Macarthur and Wilson, 1967). However, this result may simply indicate that habitat complexity is relatively low within the 0 to $20 \mathrm{~m}$ isobaths on coral reefs compared to terrestrial island biotas which often include upland habitats. Further, in the case of the Hawaiian Islands, high rates of recruitment within the archipelago may mask the effect of differences in area between the islands. This is evidence that marine ecosystems in Hawaii are more 'open' (less isolated) than are territorial ecosystems. The main barrier to colonization of marine species in Hawaii is distance; terrestrial forms must cross the same distance but in their case it represents an inhospitable barrier. Finally, the fact that species do not drop out at the northwest extremity suggests that most are generalized species with wide tolerance ranges.

Turning to differences in the community structure of reefs across the archipelago, most consist primarily of differences in species organization; that is the degree of dominance. Another feature is the disharmonic or patchy nature (both spatial and temporal) of many species. A third pattern is the progressive decrease in coral cover moving northwest in the chain. The latter effect appears to be partially the result of declining growth rates due primarily to decreases in temperature and light (Grigg, 1981b).

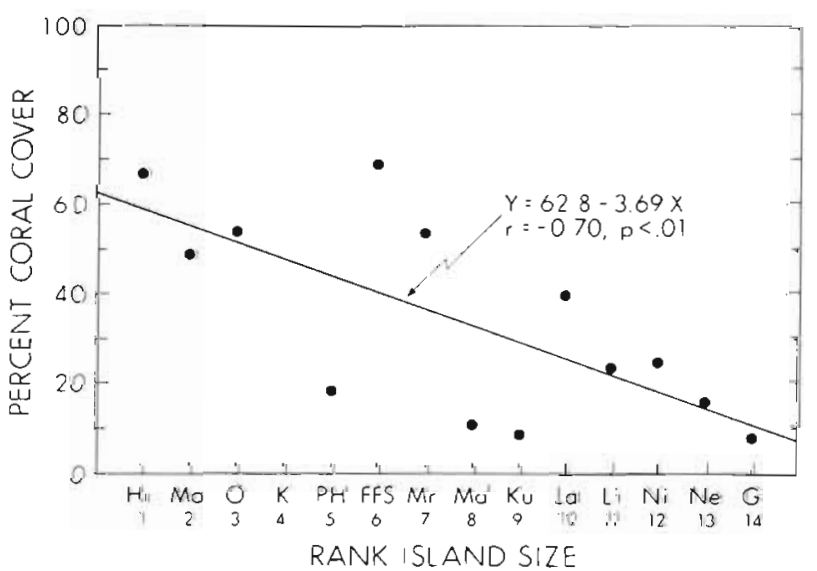

Fig. 8. Mean coral cover of southwest sector transects for each island plotted as a function of island surface area (see Table 1)
Several lines of evidence suggest that differences in dominance as well as the patchy nature of many species distributions may be caused by disturbance. Dollar (1982) has shown that the major source of disturbance to coral communities on the Kona Coast of Hawail is stress due to high waves. The same appears to be true for coral communities throughout the archipelago situated in exposed localities, including those within southwest sectors. Evidence for this is the significant relationship $(\mathrm{r}=0.7, \mathrm{p}<.01)$ between coral cover and shelter (rank island size) as shown in Fig. 8. The largest islands provide reefs off southwestern coasts with the greatest shelter from wave stress (long period swell and trade wind sea) and support reefs with the highest coral cover. In contrast, the smallest islands in the chain - Nihoa, Necker and Gardner Pinnacles - are heavily impacted by waves and are characterized by very low coral cover. These islands are virtually engulfed on all sides by refracted waves during storms and high surf.

A cause-and-effect relationship between community structure and physical disturbance by waves is also suggested by an analysis of similarity (cluster analysis) between all transects (Fig. 9). A dendrograph (Fig. 9) is produced from a similarity matrix that compares the abundance of every coral species on each transect with abundance patterns of the same species on every other transect. The distance between any 2 transects on the vertical axis of the dendrograph is proportional to their dissimilarity. Similarity within groups or clusters is represented as distance along the horizontal scale. Major clusters correspond to 5 physiographic zones related to the frequency and intensity of disturbance by waves. Diversity is low in 2 zones shown on the right (top) in Fig. 9: the surge zone where disturbance is extreme and the monopolized zone where disturbance is low and infrequent. Moving to the left (down) in the figure, diversity increases steadily. The suboptimal zone is characterized by high and frequent disturbance. Next, the intermediate zone has moderate but frequent disturbance. On the far left (bottom), the optimal zone - or zone of highest diversity - is exposed to frequent but small disturbance by waves.

The extent to which diversity is related to disturbance can be tested further by plotting mean diversity $\left(\mathrm{H}^{\prime}{ }_{\mathrm{c}}\right)$ against mean coral cover for all stations off southwest sectors for all islands. This is so because coral cover can be taken to represent the time-integrated effect of disturbance on growth at a given station. The fit is reasonably good (Fig. 10); however, there are some differences. The high values at Maro Reef, Gardner and French Frigate Shoals are perhaps higher than expected because of greater rates of recruitment associated with the Subtropical Counter-current. The cluster of low values represented by Kure, Midway, 
Fig. 9. Cluster analysis of 41 transects from a variety of habitats from all islands in the Hawaiian Archipelago. Location and depth of each transect is indicated to the right of dendrogram points. Brackets: zones and associated patterns of disturbance. Disturbance groupings based on similarity in ranks of stations to exposure to sea and swell. Species diversity increases from top to bottom

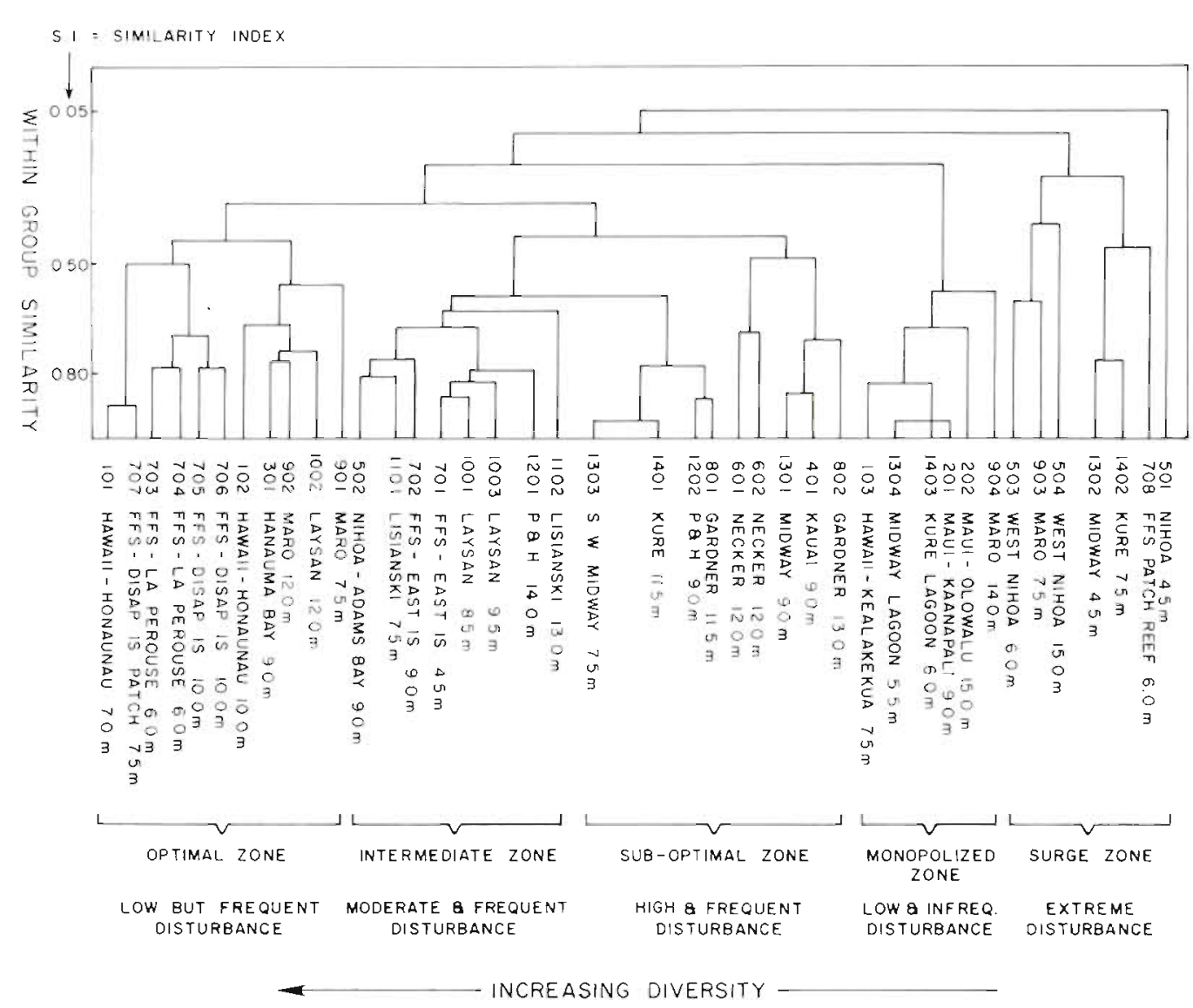

further intervening disturbance. In this way, these stations may be held in an early successional stage by a combination of disturbance and low rates of recovery. Therefore, while disturbance is important in maintaining diversity of reef communities, as convincingly argued by Connell (1978), it also appears to be the major factor controlling succession of corals in Hawaii.

Elsewhere in the world the results of a variety of studies strongly suggest that diversity, community structure and succession of coral reefs are controlled primarily by disturbance but at the same time demonstrate the variable nature of disturbance in degree and kind. At Funafuti Atoll in 1972a catastrophic disturbance in the form of a typhoon set the successional process back to zero (Maragos et al., 1974). The only thing left in the nearshore areas impacted was limestone rubble. Geister (1977), Jokiel and Maragos (1978), Smith and Jokiel (1978) and Dana (1979) all suggest that water motion and exposure to waves are major factors controlling the community structure of seaward reefs. Stoddart (1969) documented a number of cases of mass mortality to reefs from a variety of sources. Loya (1976) showed that mass mortality from unusually low tides in the Red Sea prevents resource
Fig. 10. Mean coral species diversity $\left(\mathrm{H}_{c}^{*}\right)$ for southwest sector stations for all islands plotted against mean coral cover. Curve drawn by eye represents theoretical pattern of succession 


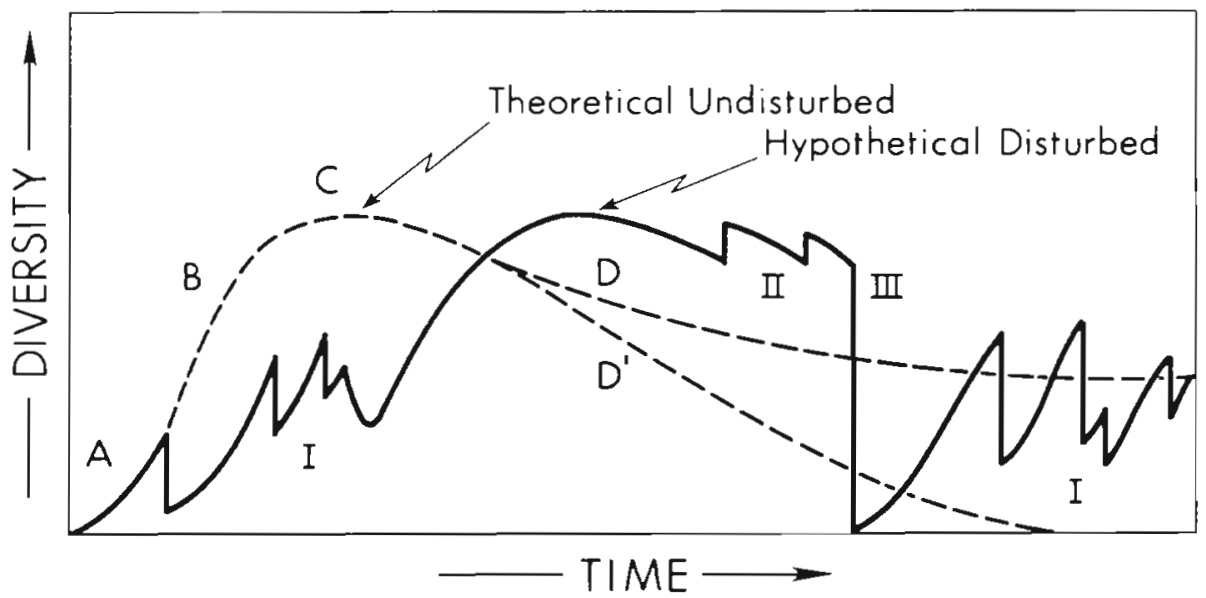

Fig. 11. Theoretical model of succession of coral reef communities and hypothetical case illustrating the effects of various intensities and frequencies of disturbance (see text for explanation) monopolization in shallow waters. Glynn (1976) stressed the variability with which physical and biological factors interact to control community structure of coral reefs in the eastern Pacific Ocean. Glynn concluded that, in general, physical factors exert the primary control in shallow water $(<8 \mathrm{~m})$, while biological factors are more important in deep water $(>8 \mathrm{~m})$. Bak and Luckhurst (1980) reached a similar conclusion for the relatively stable reefs off of Curacao, Netherlands Antilles, and noted that catastrophic events accounted for $69 \%$ of the recorded mortality over a 5-yr period. Highsmith (1980) suggested that intermediate disturbance by storms may even have a positive effect on long-term growth and calcification rates of coral reefs by broadly distributing fragments such that sea level does not retard growth.

In Fig. 11, a model of succession is presented in which expected patterns for theoretically undisturbed and hypothetically disturbed reef communities are given. In the undisturbed case, A-C represents increases in diversity due to colonization (recruitment). Diversity peaks at $\mathrm{C}$ after which competition for space gradually leads to a reduction in diversity ( $D$ and $D^{1}$ ). $D^{1}$ depicts a situation where competitive exclusion leads to almost complete monopolization of the substrate. Instances of this situation occur in Hawaii on relatively undisturbed reefs at intermediate depths where Porites lobata may occupy almost $100 \%$ of the bottom. The curve represented by $D$ may be more typical of reefs elsewhere in the world characterized by higher diversity. In these environments niche diversification (specialization), competitive networks, and compensatory mortality (Connell, 1978) may lead to the co-existence of several or even many dominant species.

In Fig. 11 disturbance events are depicted by Roman numerals. The effects of intermediate disturbance occurring at different stages of the successional process are shown by the Numerals I and II. As explained above, the effect of intermediate disturbance may be to increase or decrease diversity depending on the successional stage of a community prior to disturbance. Severe disturbance events, represented by the Num. eral III, may set the successional process back to time zero. Hence, the actual shape of the succession curve for a given reef within a given time-frame would depend primarily on the frequency and magnitude of intervening disturbances. Other processes such as substrate facilitation, differential tolerance, competition and predation are also clearly important. In Hawaii, the earliest successional stage consists of algal slimes or macroalgae (Dollar, 1982; Walsh, unpubl.) suggesting that some facilitation of the substratum may occur. Observations on lava flows (Grigg, unpubl.) and reefs heavily stressed by storms indicates that early algal colonizers die out (Walsh, unpubl.) giving way to pioneer species of coral, usually Pocillopora meandrina. Species which ultimately dominate are either the most tolerant to wave stress (Porites lobata) or competitively superior ( $P$. compressa).

Maguire and Porter (1977) have developed a theoretical computer model for eastern tropical Pacific reefs consisting of 6 species. They found the average time for an undisturbed reef to reach successional climax was $17 \mathrm{yr}$ assuming the dominant species to be the fastest growing species. Conversely, they found that by reversing the order between growth and dominance, that the time to equilibrium (climax) was almost $200 \mathrm{yr}$. Most studies of recolonization of real world reefs are hampered by the time normally required for recovery. One estimate provided by regrowth of corals on successively older lava flows in Hawaii, suggests that about 50 yr are required for full recovery (Grigg and Maragas, 1974).

In Hawaii the high degree of spatial heterogeneity or disharmony of many invertebrates and differences in rank order abundance of many corals found at many islands in the chain may both be a result of frequent 
disturbance. Reduction in coral cover would be expected to release space for the settlement of new organisms. In communities where space is non-limiting, equitability should be high and competitive processes should not have sorted out differences in chance recruitment. If communities are subject to disturbances more frequent than the time constants of recovery, disharmonic patterns of distribution and differences in rank order abundance should be common. Indeed, Kay (1980) concludes that patchiness is so common on Pacific islands that this should be considered a zoogeographic law. In conclusion, community structure of coral reefs in Hawaii appears to be largely a function of the interaction between disturbance and recovery time. Differences between reef communities sharing similar habitats on different islands can be interpreted primarily as differences in successional age.

\section{SUMMARY}

The primary mechanism controlling diversity, community structure and succession of coral reefs in Hawaii appears to be disturbance. On seaward coastlines the major source of disturbance is long-period swell. In more protected and localized environments a variety of other factors - including but not limited to, temperature, light, sedimentation, salinity, turbidity, predation and bioerosion - may be of equal or greater importance.

The species composition of corals on all islands in the chain is remarkably uniform. Where adequate foundations exist most species are present. Patchy distributional patterns of many species are probably a result of frequent disturbance. The wide distribution ranges of the most abundant corals suggests that most are generalized species with wide tolerance ranges. A lack of correlation between number of coral species and reef area was found and may be due to low habitat complexity and high rates of interisland recruitment.

Geographic position within the archipelago apparently is important primarily in terms of changing conditions in temperature and light. Both affect community structure indirectly by means of controlling coral growth. Where growth rates are slow, the successional process is retarded and the likelihood of intervening disturbance is increased. A factor of secondary importance with respect to geographic position in the chain are small differences in patterns of recruitment as evidenced by Acropora spp. Aside from these effects, community structure of coral communities in Hawaii is largely a function of the interaction between disturbance and recovery time. Differences between seaward reef communities between islands are interpreted primarily as differences in successional age.
Previous work indicates that coral reefs in Hawaii can reach successional maturity in as little as 50 yr but results in this paper show the process is usually interrupted. Climax reefs exist only in areas sheltered from wave disturbance. The time scale for development of large scale morphological features is on the order of thousands to millions of years. Dated foundations (basalts) on progressively older islands show that spur and groove systems can develop in at least 6,000 to $9,000 \mathrm{yr}$, fringing reefs 2.5 million yr and barrier reefatoll systems in about 12 million yr.

Acknowledgements. I wish to thank Steven J. Dollar, Michael Palmgren, Ted Hobson and Lisa Boucher for substantial assistance in the field. I also thank Paul Jokiel for critically reviewing the manuscript and offering helpful comments. Funding of this research by the National Sea Grant Program and the Marine Affairs Coordinator of the State of Hawaii is gratefully acknowledged.

\section{LITERATURE CITED}

Adey, W. (1978). Coral reef morphogenesis: a multi-dimensional model. Science, N. Y. 202: 831-837

Bak, R., Luckhurst, B. (1980). Constancy and change in coral reef habitats along depth gradients at Curacao. Oecologia 47: $145-155$

Barkely, R. (1968). Oceanographic atlas of the Pacific Ocean. University of Hawaii Press, Honolulu, Hawaii

Connell, J. (1978). Diversity in tropical rain forests and coral reefs. Science, N. Y. 199: 1302-1310

Connell, J., Slatyer, R. (1977). Mechanisms of succession in natural communities and their role in community stability and organization. Am. Nat. 111: 1119-1144

Dalrymple, G. B., Clague, D. A., Lanphere, M. A. (1977). Revised age for Midway volcano, Hawaiian volcanic chain. Earth Planet. Sci. Lett. 37: 107-116

Dana, $T$ (1971). On the reef corals of the world's most northern atoll (Kure: Hawaiian Archipelago). Pacif. Sci. 25: 80-87

Dana, T. (1979). Species - numbers relationships in an assemblage of reef building corals: McKean Island, Phoenix Islands. Atoll Res. Bull. 228: 1-27

Dollar, S. (1982). Wave stress and coral community structure in Hawaii. Coral Reefs 2

Edmondson, C. (1946). Reef and shore fauna of Hawaii Bishop Mus. Press, Honolulu, Hawaii

Glynn, P. (1976). Some physical and biological determinants of coral community structure in the eastern Pacific. Ecol. Monogr. 46: 431-456

Goreau, T. (1969). Post Pleistocene urban renewal in coral reefs. Micronesica 5: 323-326

Grigg, R. (1973). Some ecological effects of discharged sugar mill wastes on marine life along the Hamakua Coast, Hawaii. Water Resource Res. Center, University of Hawaii, Honolulu, Hawaii, Sem. Ser. 2: 25-45

Grigg, R. (1981a). Acropora in Hawaii. Part II. Zoogeography. Pacif. Sci. 35: 15-24

Grigg, R. (1981b). Coral reef development at high latitudes in Hawaii. In: Gomez, E. (ed.) Proceedings of Fourth International Coral Reef Symposium, Manila, P. I., in press

Grigg, R. (1982). Darwin Point: a threshold for atoll formation. Coral Reefs 1: 29-34 
Grigg, R., Dollar, S. (1980). The status of reef studies in the Hawaiian Archipelago. Grigg, R., Pfund, R. (eds.) Status of resource investigations in the Northwestern Hawailan Islands. University of Hawaii Sea Grant Publ. MR-80-04: $100-120$

Grigg, R., Maragos, J. (1974). Recolonization of hermatypic corals on submerged lava flows in Hawaii. Ecology 55: 387-395

Grigg, R., Wells, J., Wallace, C. (1981). Acropora in Hawaii. Part I. History of the scientific record, systematics and ecology. Pacif. Sci. 35: 1-13

Hobson, E. (1980). The structure of reef fish communities in the Hawaiian Archipelago: interim status report. In: Grigg, R., Pfund, R. (eds.) Status of resource investigations in the Northwestern Hawaiian Islands. University of Hawaii Sea Grant Publ. MR-80-04: 57-70

Highsmith, R., Riggs, A., D'Antonio, D. (1980). Survival of hurricane-generated coral fragments and a disturbance model of reef calcification/growth rates. Oceologia 46 : 322-329

Highsmith, R. C. (1982). Reproduction by fragmentation in corals. Mar. Ecol. Prog. Ser. 7: 207-226

Hirota, J., Taguchi, S., Shuman, R., Jahn, A. (1980). Distributions of plankton stocks, productivity and potential fishery yield in Hawaiian waters. In: Grigg, R., Pfund, R. (eds.) Status of resource investigations in the Northwestern Hawaiian Islands. University of Hawaii Sea Grant Publ. MR-80-04: 191-203

Jackson, E., Koizumi, I., Dalrymple, G., Clague, D., Kirkpatrick, R., Greene, H. (1980). Introduction and summary of results from DSDP Leg 55, the Hawaiian - Emperor hotspot experiment. In: Shamback, J. (ed.) Initial reports of the Deep Sea Drilling Project, Vol. 55. U. S. Governmental Printing Office, Washington, D. C. 20402, p. 5-31

Johannes, R., Wood, F. (1975). Tropical marine pollution. Elsevier Oceanogr. Ser. Vol. 12, Elsevier Publ. Co., Amsterdam

Jokiel, P., Coles, S. (1977). Effects of temperature on the mortality and growth of Hawaiian reef corals. Mar. Biol. 43: 201-208

Kay, A. (1980). Little worlds of the Pacific: an essay on Pacific basin biogeography, Publ. H. Lyon Arboretum, University of Hawaii

Ladd, H., Tracey, J., Gross, G. (1967). Drilling on Midway Atoll, Hawaii. Science, N. Y. 156: 1088-1093

Loya, Y. (1976). Recolonization of Red Sea corals affected by natural catastrophes and man-made perturbations. Ecology $57: 278-289$

Macarthur, R., Wilson, E. (1967). The theory of island biogeography. Princeton University Press, Princeton, N. J.

Macintyre, I., Glynn, P. (1976). Evolution of modern Caribbean fringing reef, Galeta Point, Panama. Am. Ass. Pet. Geol. Bull. 60: 1054-1072

Maguire, L., Porter, J. (1977). A spatial model of growth and competition strategies in coral communities. Ecol. Modelling 3: $249-271$

Maragos, J. (1972). A study of the ecology of Hawaiian reef corals. Ph. D. thesis, University of Hawaii, Honolulu

Maragos, J. (1977). Order Scleractinia, stony corals. In: Devaney, D., Eldredge, L. (eds.) Reef and shore fauna of Hawaii. Bishop Mus. Press, Honolulu, Hawaii

Maragos, J., Baines, G., Beveridge, P. (1973). Tropical cyclone Bebe creates a new land formation on Funafuti Atoll. Science, N. Y. 181: 1161-1164

Morgan, W. (1972). Deep mantle convection plumes and plate motions. Am. Ass. Pet. Geol. Bull. 56: 203-213

Patzert, W., Wyrtki, K., Santamore, H. (1970). Current measurements in the central north Pacific Ocean. Hawaii Inst. of Geophysics, Vol. 70-30. University of Hawaii, Honolulu

Pearson, R. G. (1981). Recovery and recolonization of coral reefs. Mar. Ecol. Prog. Ser. 4: 105-122

Pichon, M. (1977). Recent studies on the reef corals of the Philippine Islands and their zoogeography. In: Taylor, D. L. (ed.) Proceedings of the third international coral reef symposium, Vol. 1. University of Miami, Miami, p. 149-154

Robinson, M. (1976). Atlas of North Pacific monthly mean temperatures and salinities of the surface layer Naval Oceanogr. Office, Ref. Pub. 2, D. O. D., Wash. D. C

Rotondo, G., Springer, V., Scott, G., Schlanger, S. (1981). Plate movement and island integration - A possible mechanism in the formation of endemic biotas with special reference to the Hawaiian Islands. Syst. Zool., in press

Sadler, J., Oda, L., Kilonsky, B. (1976). Pacific Ocean cloudiness from satellite observations. Dept. of Meteorology, Vol. 76-01. University of Hawaii, Honolulu

Schlanger, S., Gillett, G. (1976). A geological perspective of the upland biota of Laysan Atoll (Hawaiian Islands). Biol. J. Linn. Soc. 8: 205-216

Sechel, G. (1962). Atlas of oceanographic climate of the Hawaiian Islands Region. Fish. Bull. U. S. 193: 371-427

Smith, S., Chave, K., Kam, D. (1973). Atlas of Kaneohe Bay: a reef ecosystem under stress. University of Hawaii Sea Grant Program, Honolulu, Hawaii

Stehli, F., Wells, J. (1971). Diversity and age patterns in hermatypic corals. Syst. Zool. 20: 115-126

Stoddart, D. (1969). Ecology and morphology of recent coral reefs. Biol. Rev. 44: 433-498

Wilson, J. (1963). A possible origin of the Hawaiian Islands Can. J. Physics 41: 863-870

Wyrtki, K., Graefe, V., Patzert, W. (1969). Current observations in the Hawaiian Archipelago. Hawaii Institute of Geophysics, Vol. 69-15, University of Hawaii, Honolulu, p. 1-27

Zinmeister, W., Emerson, W. (1979). The role of passive dispersal in the distribution of hemipelagic invertebrates with examples from the tropical Pacific Ocean. The Veliger 22: $32-40$ 